\title{
Climate-induced changes in the trophic status of a Central European lake
}

\author{
Emiliya KIRILOVA ${ }^{1)} *$, Oliver HEIRI ${ }^{1)}$, Dirk ENTERS ${ }^{2,4)}$, Holger CREMER $^{3)}$, André F. LOTTER ${ }^{1)}$, \\ Bernd ZOLITSCHKA ${ }^{2)}$ and Thomas HÜBENER ${ }^{5)}$ \\ ${ }^{1)}$ Palaeoecology, Institute of Environmental Biology, Utrecht University, Laboratory of Palynology and Palaeobotany, Budapestlaan \\ 4, 3584 CD Utrecht, The Netherlands \\ ${ }^{2)}$ Geopolar, Geomorphology and Polar Research, Institute of Geography, University of Bremen, Celsiusstr. FVG-M, 28359 Bremen, \\ Germany \\ ${ }^{3)}$ Netherlands Organization for Applied Scientific Research TNO, National Geological Survey, Princetonlaan 6, 3584 CB Utrecht, \\ The Netherlands \\ 4)UMR CNRS 5204, EDYTEM, Université de Savoie - Technolac, F-73376 Le Bourget du Lac, France \\ ${ }^{5}$ Department of Biodiversity, University of Rostock, Wismarsche Straße 8, 18057 Rostock, Germany \\ *e-mail corresponding author: e.p.kirilova@uu.nl
}

\begin{abstract}
We present a case study of the development of Sacrower See, a stratified, eutrophic lake in northeastern Germany, over the past 13,000 years. Total epilimnetic phosphorus (TP) concentrations were reconstructed quantitatively using a diatom-TP transfer function. Fossil chironomid assemblages were used to support the trophic reconstruction and helped assessing past hypolimnetic oxygen availability. The results indicate eutrophic and anoxic conditions during the Younger Dryas cold period ( 12,700-11,600 cal. $B P)$ preceding the present interglacial. Throughout the early and mid-Holocene ( 11,600-4000 cal. BP) stable oligo- to mesotrophic conditions with diatom-inferred TP values of $\sim 20 \mu \mathrm{g} \mathrm{L} L^{-1}$ prevailed. First evidence of increasing Holocene TP is recorded at $\sim 3500$ cal. BP associated with Bronze Age human impact and for the past 900 years diatoms indicate increasing TP values of $30-60 \mu g L^{-1}$. During the early Holocene and the past two millennia chironomids indicated anoxic hypolimnetic conditions. The chironomid fauna is considered typical of oligo- to mesotrophic lakes. As a consequence of strongly increased primary production the hypolimnion of Sacrower See became anoxic again during the past 140 years. Our results indicate that highly productive eutrophic conditions can exist prior to cultural eutrophication. At Sacrower See the shift from eutrophic conditions in the Lateglacial to oligo-mesotrophic conditions in the early and mid-Holocene was associated with the climatic warming at the Younger Dryas/Holocene transition. The high productive state during the cold Younger Dryas is associated with changes in seasonality: the prolonged winters caused longer ice cover, stronger stratification, anoxia in the hypolimnion, and consequent internal phosphorus loading. During the warm Holocene, however, hypolimnetic anoxia and internal phosphorus loading decreased significantly, resulting in a substantially lower productivity.
\end{abstract}

Key words: palaeolimnology, total phosphorus, oxygen, diatoms, chironomids, climate change

\section{INTRODUCTION}

Nutrient enrichment has become a major threat to freshwater ecosystems (e.g., Smol 2008) and has consequently received considerable attention on the political agenda. Climate change in combination with human induced eutrophication of lakes via nutrient loading through agriculture, industry, sewage release, and soil erosion can lead to adverse consequences for ecosystem functioning and services. As a consequence of such anthropogenic nutrient enrichment lakes may experience harmful algal blooms, oxygen depletion, decreased biodiversity, and/or massive fish kills (Moss 2008; Schindler 2001). Some lakes are, however, naturally nutrient-rich due to the local geological or morphological setting, whereas others can experience moderate nutrient enrichment throughout their history as a consequence of natural processes such as abiotic or plant-mediated weathering and transport of nutrients from the catchment to the lake (e.g., Engstrom et al. 2000). Nevertheless, it is widely accepted that most temperate
European lakes would be oligo- to perhaps mesotrophic in a natural, undisturbed setting and in the absence of human impact.

When defining restoration targets for nutrientenriched lakes, the lack of pristine reference sites coupled with limited availability of high-quality and longterm monitoring data are a major concern (Moss 2008). Where available, monitoring programs are usually initiated only after the signs of disturbance are evident. The lacustrine sediment record provides an alternative natural archive which allows the reconstruction of long-term ecosystem processes and the assessment of baseline conditions with regard to nutrients and ecosystem functioning which are essential for defining lake restoration aims (e.g., Bennion \& Battarbee 2007). Indicator organisms, such as diatoms and chironomids (non-biting midges) that preserve as microfossils in the sedimentary record, are exceptionally useful for inferring past trophic conditions in lakes. Diatoms have been shown to be highly sensitive to changes in lake $\mathrm{pH}$ and nutrient concentrations (e.g., Stoermer \& Smol 1999). The 


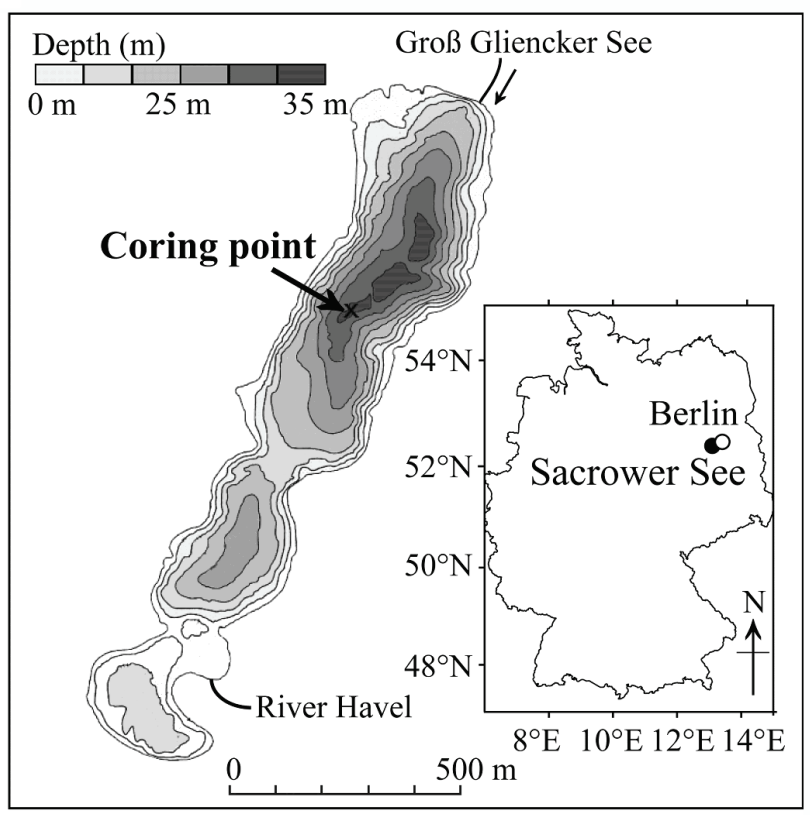

Fig. 1. Location of Sacrower See in an outline map of Germany and bathymetric map of the lake basin.

strong empirical relationship between nutrients and diatom assemblages (e.g., Bennion et al. 1996; Anderson 1997; Hall \& Smol 1999) has been successfully used to infer past epilimnetic total phosphorus (TP) concentrations (e.g., Wunsman \& Schmidt 1995; Lotter 1998; Bennion et al. 2000). Similarly, the analysis of chironomid assemblages can provide insights into the trophic state of lakes, especially in deep, stratified systems (e.g., Saether 1979). Since parts of these animals are well preserved as fossils in lake sediments, remains of chironomid larvae can be used for reconstructing TP and changes in hypolimnetic oxygen availability, both using qualitative (e.g., Itkonen et al. 1999; Heiri \& Lotter 2003) and quantitative approaches (e.g., Lotter et al. 1998; Brooks et al. 2001; Little \& Smol 2001).

Here, we present a palaeolimnological case-study on the long-term trophic development of Sacrower See, a lowland lake in Northeastern Germany. We report an unusual case of climate-induced trophic change under undisturbed, pre-anthropogenic conditions in a deep, stratified lake. Based on fossil diatoms from a continuous sediment record we reconstruct epilimnetic TP throughout the past 13,000 years and discuss factors affecting the lake's nutrient levels. Moreover, remains of chironomids are used as semi-quantitative indicators of hypolimnetic oxygen conditions and independent evidence for changes in trophic state as reconstructed by diatom assemblages.

\section{STUDY AREA}

Sacrower See is a eutrophic hardwater lake situated in Brandenburg, Germany (Fig. 1), at an elevation of $29.5 \mathrm{~m}$ a.s.l. (Tab. 1). The lake was formed during the
Weichselian glaciation and presently has a maximum water depth of $38 \mathrm{~m}$ (Tab. 1). It is connected hydrologically (subsurface inflow) in the northeast with Groß Glienicker See and in the south with the River Havel via an artificial channel and subsurface in- and outflow (Fig. 1). The lake is dimictic and anoxic conditions often develop in the lake's hypolimnion during summer stagnation (Bluszcz et al. 2008) but also during winter and autumn.

Tab. 1. Basic morphometric, limnological, and climatic parameters characterizing Sacrower See (after Bluszcz et al. 2008).

\begin{tabular}{lc}
\hline Altitude & $29.5 \mathrm{~m}$ a.s.l. \\
Catchment area & $35.3 \mathrm{~km}^{2}$ \\
Surface area & $1.07 \mathrm{~km}^{2}$ \\
Volume & $19.3 \times 10^{6} \mathrm{~m}^{3}$ \\
Maximum depth & $38 \mathrm{~m}$ \\
Mean depth & $18 \mathrm{~m}$ \\
Mean water residence time & $12-15$ years \\
Stratification period & Apr-Nov \\
Mean annual precipitation & $603 \mathrm{~mm}$ \\
Mean summer air temperature & $17^{\circ} \mathrm{C}$ \\
Mean annual air temperature & $9.6^{\circ} \mathrm{C}$ \\
\hline
\end{tabular}

\section{MATERIAL AND METHODS}

A $17 \mathrm{~m}$ long sediment sequence was retrieved in 2005 from the deepest part of Sacrower See at a water depth of $38 \mathrm{~m}$ (Fig. 1) using a modified Livingstone piston corer. The sediments consist of organic-rich calcareous gyttja with distinctly annually laminated sections in the top $40 \mathrm{~cm}$ and below $859 \mathrm{~cm}$. The lowermost sediment unit consists of homogeneous, slightly graded sands with occasional lignite fragments interpreted as a slump deposit and consequently omitted 
Tab. 2. Radiocarbon dates from the Sacrower See sediment core (Enters et al., accepted).

\begin{tabular}{|c|c|c|c|c|c|c|}
\hline $\begin{array}{l}\text { Composite depth } \\
(\mathrm{cm})\end{array}$ & Lab. No. & Analyzed fraction & $\begin{array}{l}\delta^{13} \mathrm{C} \\
(\%)\end{array}$ & ${ }^{14} \mathrm{C}$ Age & $\begin{array}{l}{ }^{14} \mathrm{C} \text { Age } \\
\text { (BP) } \pm \mathrm{SD}\end{array}$ & 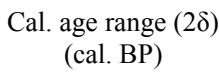 \\
\hline 0 & - & Sediment surface & - & - & - & -55 \\
\hline 39.5 & - & Varves & - & - & - & $74-86 a$ \\
\hline $63-64$ & Poz-6086 & Unidentified leaf remains & -26.5 & 220 & \pm 30 & $140-310$ \\
\hline $136-138$ & UtC 14516 & Quercus leaf & -29.2 & 381 & \pm 32 & $310-510$ \\
\hline $272-273$ & UtC 14517 & Unidentified leaf remains & -28.6 & 1215 & \pm 35 & $1050-1270$ \\
\hline $417-418$ & UtC 14518 & Unidentified leaf remains & -27.3 & 2180 & \pm 37 & $2060-2330$ \\
\hline $512-513$ & UtC 14519 & Unidentified leaf remains & -27.9 & 2840 & \pm 34 & $2860-3070$ \\
\hline $593-595$ & UtC 14520 & Unidentified leaf remains & -28.0 & 3505 & \pm 39 & $3680-3890$ \\
\hline $671.5-672.5$ & UtC 14521 & Unidentified leaf remains; Alnus glutinosa catkin scales & -28.6 & 4252 & \pm 37 & $4640-4880$ \\
\hline 784-786 & UtC 14522 & Betula fruit; c.f. Pinus cone axis and scale leaves & -29.3 & 5640 & \pm 90 & $6280-6660$ \\
\hline $892-893$ & UtC 14523 & c.f. Pinus scale leaves and (charred) leaf remains & -28.6 & 7920 & \pm 50 & $8600-8980$ \\
\hline $1002-1003$ & UtC 14524 & c.f. Pinus scale leaves & -23.1 & 10180 & \pm 130 & $(12150-12815)$ \\
\hline 1014-1015 & Poz-21521 & c.f. Pinus bark & -24.8 & 9500 & \pm 50 & $10580-11080$ \\
\hline $1107-1108$ & UtC 14525 & Betula fruit, Poytrichum leaves, unidentified leaf remains & -27.5 & 10840 & \pm 60 & $(12875-12815)$ \\
\hline $1173-1176$ & - & Laacher See tephra & - & - & - & $12790-12970 \mathrm{~b}$ \\
\hline
\end{tabular}

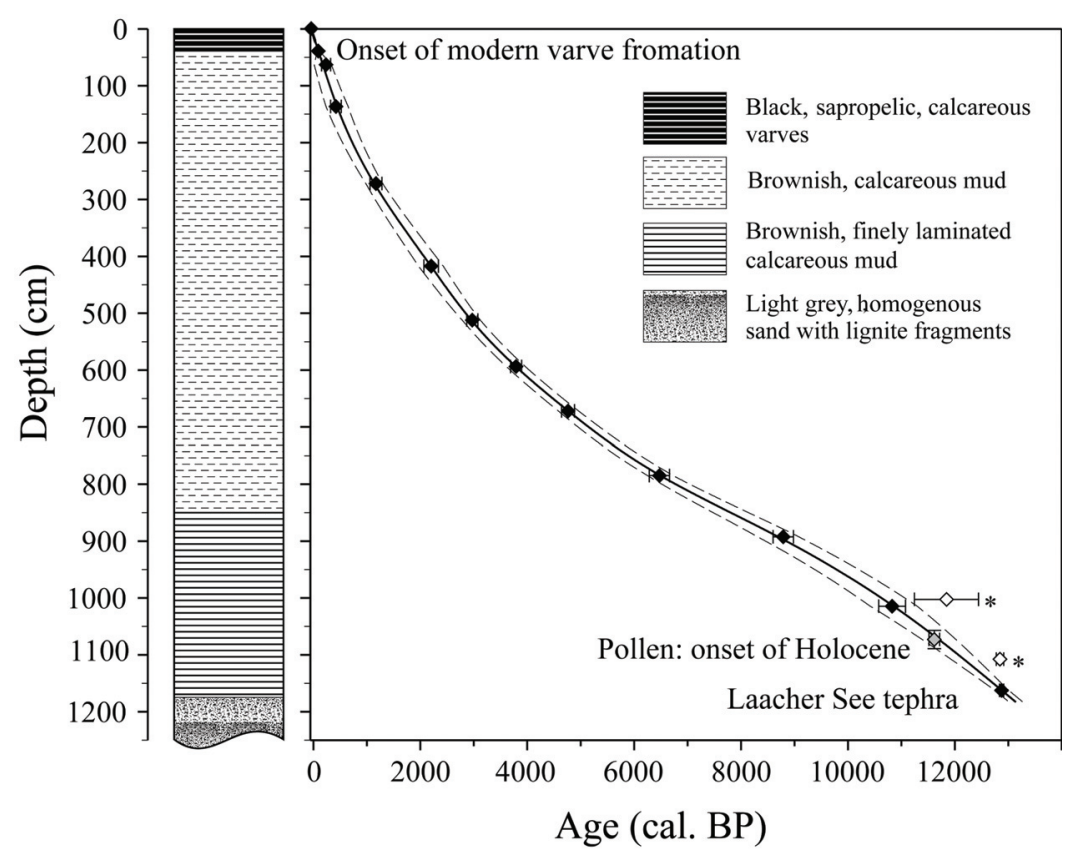

Fig. 2. Dating of the sediment core and age-depth relationship. Dashed lines mark the $95 \%$ confidence intervals. The two ${ }^{14} \mathrm{C}$ dates not included in the age-depth model are marked with stars.

from analysis together with an additional slump at 1130 $1239 \mathrm{~cm}$ depth. This resulted in a final composite sediment profile with a total length of $1183 \mathrm{~cm}$.

The chronology of the sediment record is based on 12 AMS ${ }^{14} \mathrm{C}$ dates measured on terrestrial plant remains (see Tab. 2), the Laacher See Tephra dated to

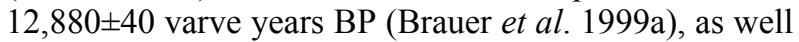
as ${ }^{210} \mathrm{~Pb}$ and ${ }^{137} \mathrm{Cs}$ dating (Lüder et al. 2006). ${ }^{14} \mathrm{C}$ dates were transformed to calibrated ${ }^{14} \mathrm{C}$ years before present (cal. BP) using the program Calib 5.0.2 and the INTCAL04 calibration curve (Reimer et al. 2004). Agedepth modeling was performed using a generalized mixed-effect regression model (Heegaard et al. 2005; Fig. 2). Two radiocarbon dates in the lower part of the record were clearly too old and were therefore excluded. Preliminary pollen analysis located the onset of the
Holocene (i.e., the past $c a$ 11,600 years) between 1057 and $1089 \mathrm{~cm}$ sediment depth.

Titanium (Ti) was measured by X-ray fluorescence (XRF) analysis on split core surfaces as indicator of soil erosion. For diatom analysis 90 samples were digested with $30 \% \mathrm{H}_{2} \mathrm{O}_{2}$ to remove organic matter. Further details regarding the age-depth model, geochemistry and pollen data are described in Enters et al. (accepted). Microscope slides were prepared using the sedimentation tray method (Battarbee 1973) and Naphrax ${ }^{\circledR}$ mounting medium. A minimum of 500 valves was counted on each slide under a light microscope at $1000 \times$ magnification using differential interference contrast optics. Taxonomy follows Krammer \& Lange-Bertalot (1986, 1988, 1991a, 1991b), Håkansson (2002), and, for Fragilaria, Round et al. (1990) and Compère (2001). 
A diatom TP transfer-function, based on a combined European diatom data-base (EDDI, http://craticula.ncl. ac.uk/Eddi/jsp/) and a Mecklenburg-Vorpommern (Northeastern Germany) calibration dataset (Adler \& Hübener 2007; http://www.biologie.uni-rostock.de/abt/botanik/ AG-Phykologie/), was used for quantitative TP reconstruction. The modern diatom training set consists of 429 samples and covers a range of 2-1189 $\mu \mathrm{g} \mathrm{TP} \mathrm{L^{-1 }}$. Diatom-based TP inference is based on weighted averaging partial least squares (WA-PLS) regression and calibration (Ter Braak \& Juggins 1993) of squareroot transformed diatom percentage data and log transformed TP and was calculated using the software C2 version 1.5 (Juggins 2007). The model features a root mean square error of prediction (RMSEP) of 0.28 $\log$ TP units and a coefficient of determination $\left(r^{2}\right)$ of 0.73 as evaluated by leave-one-out cross-validation methods.

Chironomid assemblages from 44 sediment samples were analyzed and identified following Brooks et al. (2007). Samples were treated with $10 \% \mathrm{KOH}$ and sieved with a $100 \mu \mathrm{m}$ sieve. Chironomid head capsules (hc) and other arthropod remains were sorted from the sieve residue using a dissecting microscope.

Chironomid concentrations were very low in the record and adjacent samples had to be amalgamated to reach more reliable count sums. Since chironomid counts still remained well below the 45-50 he per sample recommended for quantitative reconstruction (Heiri \& Lotter 2001; Quinlan \& Smol 2001), no further numerical analyses were attempted.

\section{RESULTS}

\subsection{Diatom assemblage changes}

In total 90 diatom assemblages were analyzed in the Sacrower See record. The diatom succession was subdivided into five significant zones as assessed using optimal zonation and the broken stick model (Fig. 3).

In the lowermost zone, Z1 $(1184-1057 \mathrm{~cm})$ diatom assemblages were dominated by Fragilaria spp. (including Fragilaria, Ulnaria, Staurosira, Staurosirella, Synedra, and Pseudostaurosira) and Stephanodiscus spp. The most abundant diatom species in this period were Staurosira construens f. venter, Fragilaria tenera, Ulnaria ulna, Stephanodiscus neoastraea, and Stephanodiscus parvus. Chrysophycean statocysts had a high abundance only in the lowermost part of this section.

During zone Z2 $(1057-611 \mathrm{~cm})$ Cyclotella cyclopuncta was the dominating diatom. Also, Cyclotella ocellata, Puncticulata bodanica, Puncticulata radiosa, Fragilaria spp., and S. neoastraea frequently occurred in this zone. In contrast, diatoms dominating the previous zone such as $S$. costruens f. venter, Stephanodiscus minutulus or $S$. parvus mostly disappeared from the record. Around $963 \mathrm{~cm} \mathrm{S.} \mathrm{parvus} \mathrm{briefly} \mathrm{reappeared} \mathrm{at}$ low abundances. Chrysophycean statocysts increased in abundance and had a peak between $819-755 \mathrm{~cm}$.
In Z3 $(611-227 \mathrm{~cm})$, the assemblages were dominated by Cyclotella comensis $(5-80 \%)$ and S. neoastraea $(10-40 \%)$. P. bodanica and Stephanodiscus alpinus also occurred in relatively high frequencies. Fragilaria spp. was present at low percentage values throughout the entire zone. S. parvus appeared at very low abundances at the beginning of this zone. In contrast with the transition between Z1 and Z2, which was fairly abrupt, the transition between Z2 and Z3 was more gradual in the diatom assemblages of Sacrower See. Chrysophycean statocysts showed low abundances in the entire zone $\mathrm{Z3}$.

In Z4 (227-115 cm), Aulacoseira islandica and Tabellaria flocculosa increased their abundances and became the dominant species. S. neoastraea and $C$. comensis were subdominant species in this section. $C$. comensis and $P$. bodanica, two diatoms abundant in the previous zone, almost disappeared from the assemblages. Similarly, chrysophycean cysts, present at low abundances in the previous zone, are no longer present in Z4.

In Z5 $(115-0 \mathrm{~cm})$ diatom assemblages were dominated by $S$. neoastraea, S. parvus, and S. alpinus. A. islandica, Fragilaria spp. and C. comensis showed increased abundances at the onset of $\mathrm{Z5}$, but were absent from the uppermost sediment layers. Aulacoseira islandica and T. flocculosa have strongly reduced abundances in Z5 compared with the previous diatom assemblage zone.

\subsection{Chironomids}

In the lowermost sediments of Sacrower See $(>1080$ $\mathrm{cm})$ chironomid assemblages are dominated by taxa such as Stictochironomus, Micropsectra radialis-type, Tanytarsus lugens-type, Paratanytarsus penicillatustype, and Tanytarsus mendax-type (Fig. 4). At the transition between zone $\mathrm{C} 1$ and $\mathrm{C} 2(1080 \mathrm{~cm})$ a number of chironomids such as $M$. radialis-type and Tanytarsus lugens-type disappear from the sediments, whereas others, e.g., Corynocera ambigua, Paratanytarsus penicillatus-type and Tanytarsus mendax-type, show no major change in abundances. In zone C3 $(1020-650 \mathrm{~cm})$ assemblages are dominated by taxa such as $M$. radialistype, Heterotrissocladius grimshawi-type, Micropsectra insignilobus-type, T. mendax-type and from ca $850 \mathrm{~cm}$ onwards Sergentia coracina-type. In zone C4 (650-380 $\mathrm{cm}) S$. coracina-type is the dominating chironomid in Sacrower See. Furthermore, a number of taxa which were already present in $\mathrm{C} 1$ and $\mathrm{C} 2$ reappear in the assemblages, e.g. Microtendipes and P. penicillatustype. In C5 $(250-380 \mathrm{~cm}) S$. coracina-type is still present, although in lower abundances than in the previous zone. Furthermore, taxa such as Parakiefferiella bathophila-type and Tanytarsus pallidicornis-type 1 occur in the samples. In C6 $(150-250 \mathrm{~cm}) S$. coracina-type, $P$. penicillatus-type, and P. bathophila-type are still present in the sediments. 


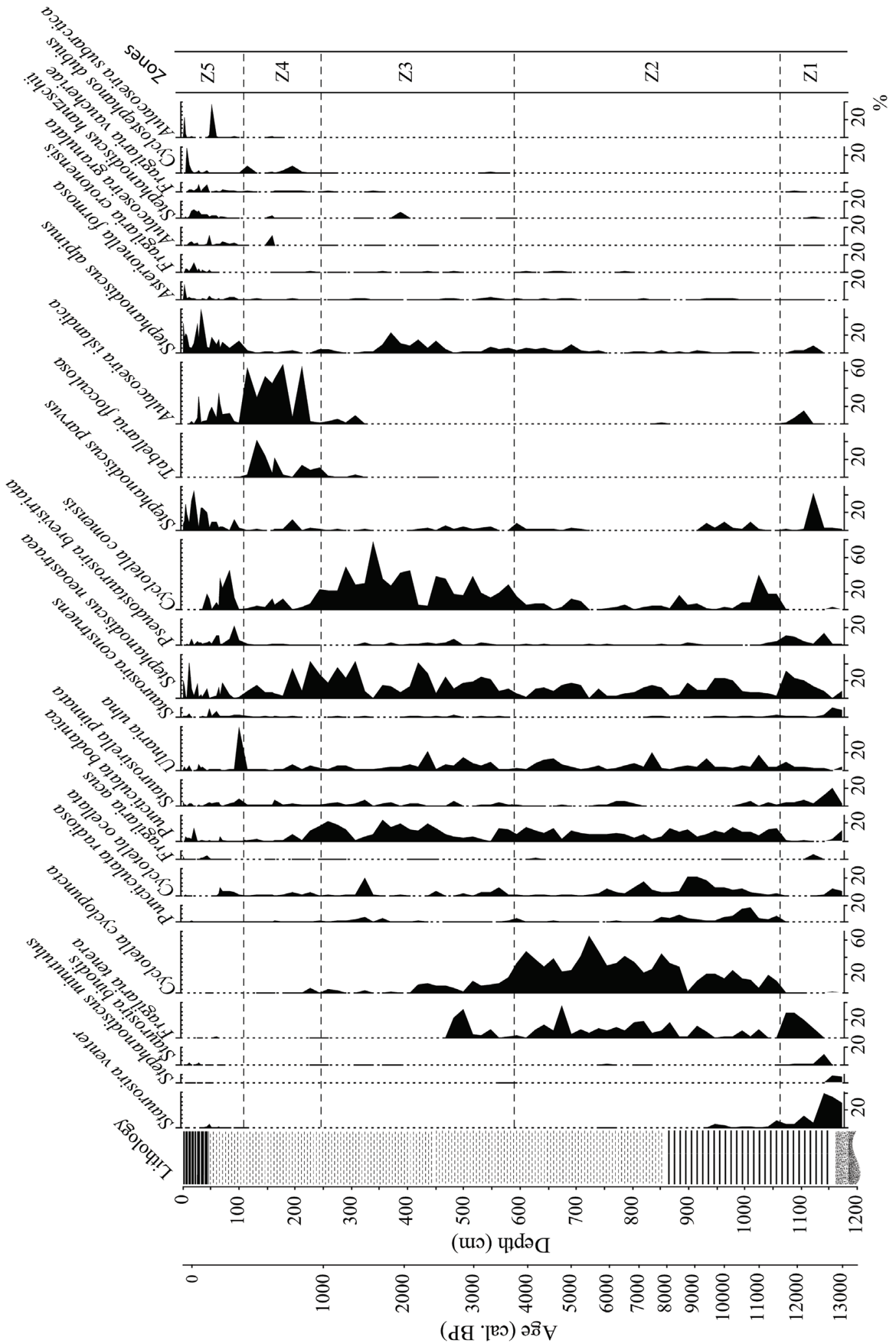

Fig. 3. Diatom assemblages in the sediments of Sacrower See (as \% of the total number of counted diatoms). 


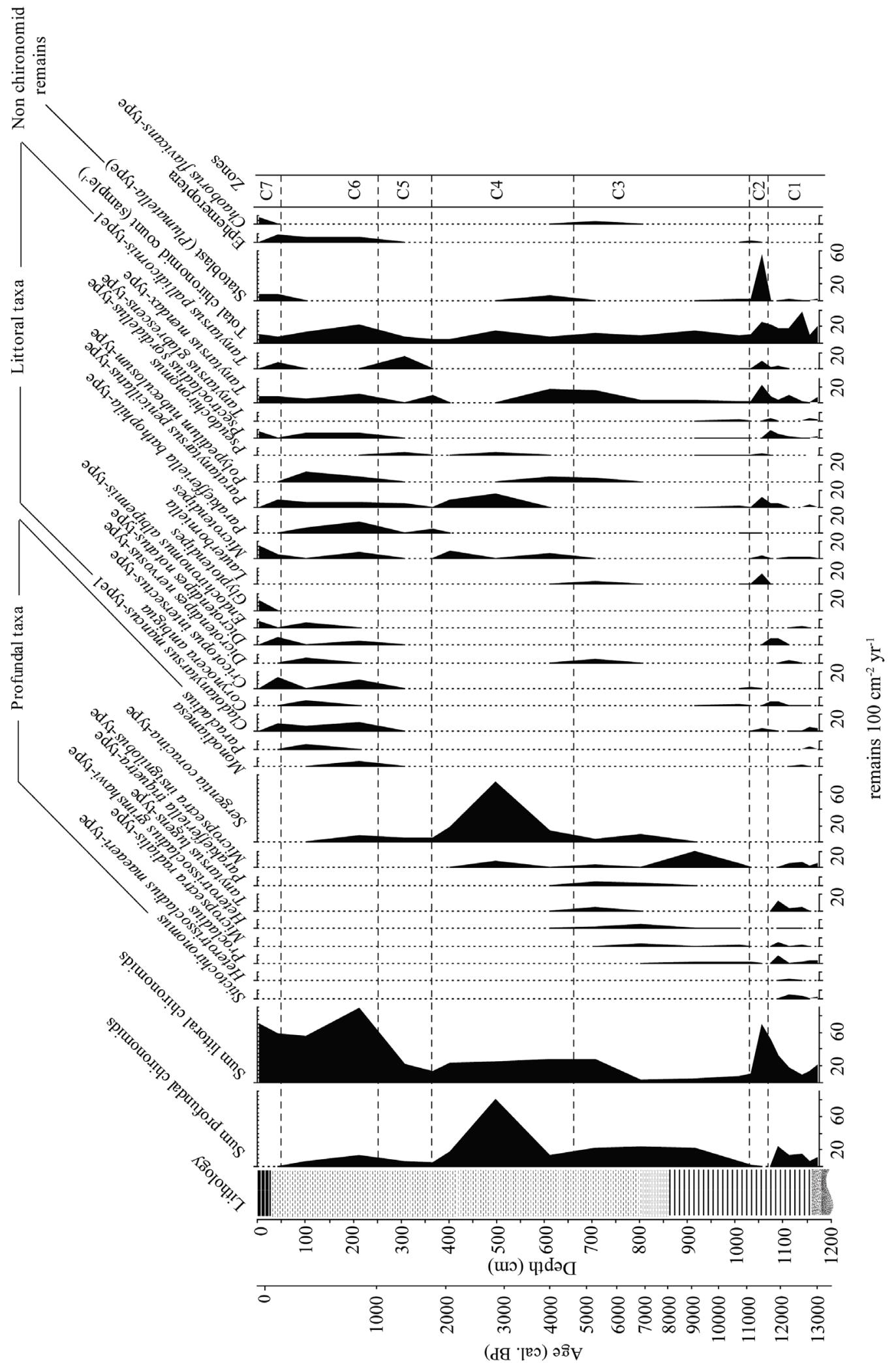

Fig. 4. Accumulation rates of fossil chironomids (as chironomid head capsules per $100 \mathrm{~cm}^{2}$ per year) and some other invertebrate taxa (as remains per $100 \mathrm{~cm}^{2}$ per year) in the sediments of Sacrower See. 


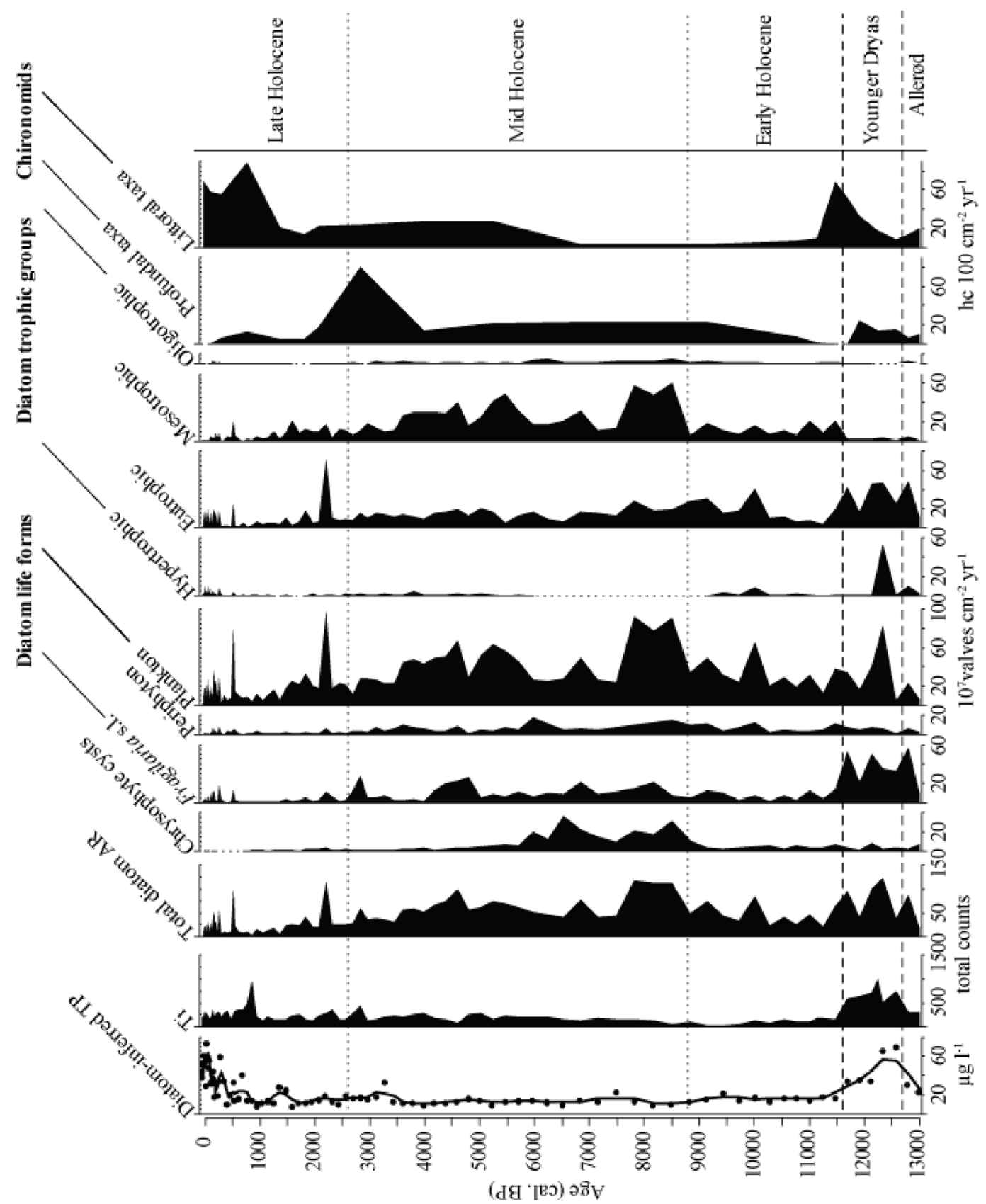

Fig. 5. Diatom-inferred total phosphorus concentration and accumulation rates (AR) for chrysophyte cysts, diatom valves grouped by life-form and trophic category (after Van Dam et al. 1994), and for chironomids grouped by habitat preference.

These taxa are joined by chironomids such as Monodiamesa, Polypedilum nubeculosum-type, Dicrotendipes notatus-type, Cricotopus intersectus-type and Cladotanytarsus mancus-type1. In the uppermost zone C7 $(150-0 \mathrm{~cm})$, finally, S. coracina-type is absent from the sediment samples, whereas many of the chironomid taxa present in $\mathrm{C} 6$ or $\mathrm{C} 5$ persevere in the lake.

\subsection{Diatom-based TP reconstruction}

Diatom-inferred TP (Fig. 5) indicates high nutrient availability in the lowermost part of the record $(>1050$ $\mathrm{cm})$. Starting with values of $24-30 \mu \mathrm{g} \mathrm{L}^{-1}$, TP rises to reach maximum values of $\sim 50-70 \mu \mathrm{g} \mathrm{L}^{-1}$ at $1170-1130$ $\mathrm{cm}$ sediment depth. Diatom assemblages indicate decreasing TP values thereafter and comparatively low $\mathrm{TP}$ of $10-20 \mu \mathrm{g} \mathrm{L}^{-1}$ is inferred $1050-220 \mathrm{~cm}$. In Z4 (220$110 \mathrm{~cm}$ ) reconstructed TP values are very variable and increase again to reach smoothed values around 20-30 $\mu \mathrm{g} \mathrm{L}^{-1}$. In the uppermost part of the sequence diatominferred TP continues to increase to reach maximum values of $60-70 \mu \mathrm{g} \mathrm{L}^{-1}$ at $c a 30-50 \mathrm{~cm}$ below the sediment-water interface before decreasing again slightly in the in the surfical sediments. 


\section{DISCUSSION}

Diatom (Fig. 3) and chironomid assemblages (Fig. 4) indicate that the trophic conditions in Sacrower See and the oxygen availability for the benthic fauna have varied distinctly throughout the past 13,000 years. Between $\sim 13,000$ and 11,550 cal. BP diatom-inferred TP (DI-TP) (Fig 5) is comparable to present-day epilimnetic TP concentrations (Fig 3). During this period of the Lateglacial diatoms typical of eutrophic to hypertrophic lakes, such as Stephanodiscus parvus, $S$. minutulus, S. neoastraea, S. alpinus, S. hantzschii, and of prolonged ice-cover (Douglas \& Smol 1999; Lotter \& Bigler 2000), such as Fragilaria sensu lato (s.l. e.g., F. tenera), were abundant. Fossil chironomid assemblages (Fig. 4) during this phase included taxa typical of both profundal and littoral environments. However, many of the chironomids typically restricted to the profundal in temperate lowland lakes can colonize littoral habitats under colder climatic conditions (e.g., Brundin 1949) such as during the Younger Dryas cold phase $(\sim 12,700$ $11,600 \mathrm{cal}$. BP). In this interval, which represents the last major cold phase of the last glaciation, Stictochironomus was present in Sacrower See. This chironomid is commonly found in inorganic sediments in lakes with elevated nutrient conditions (Saether 1979; Heiri \& Lotter 2008) and its larvae feature relatively high hemoglobin concentrations (Int Panis et al. 1996). The presence of Stictochironomus suggests at least seasonally low oxygen concentrations in the lake's bottom water. However, the relatively high accumulation rate of chironomid fossils during the same interval (Fig. 5) indicates that oxygen levels were still sufficient to support larval chironomid populations at or close to the coring site.

Unexpectedly high DI-TP values $\left(\sim 70 \mu \mathrm{g} \mathrm{L}^{-1}\right)$ are inferred for Sacrower See during the Younger Dryas cold phase ( 11,600-12,700 cal. BP, see Fig. 5). Intensified internal recycling of orthophosphate is a mechanism which could explain such high DI-TP values under pre-anthropogenic conditions. The Younger Dryas cold phase is characterized by a marked increase in seasonality (Renssen \& Isarin 2001; Brauer et al. 2008). During periods of cooler climate and more severe winters, prolonged ice cover can lead to more stable and longer winter stratification. In deep lake basins this can cause prolonged phases of anoxia (e.g., Asikainen et al. 2007). Since redox conditions strongly influence the stability of phosphate in the sediments, this in turn may lead to a significant phosphorus release (e.g., Carignan \& Flett 1981; Moosmann et al. 2006; Spears et al. 2008). Such internal loading may exceed the external phosphorus load (e.g., Søndergaard et al. 2001). At present, internal loading is at least partly responsible for maintaining high TP concentrations in Sacrower See. Owing to the low oxygen availability during summer stagnation, hypolimnetic phosphate concentrations in the lake may reach extremely high values (up to $4600 \mu \mathrm{g} \mathrm{L}^{-1}$ ) due to remobilization of phosphorus from the sediments (Bluszcz et al. 2008). During autumn or spring circulation these nutrients are mixed into the photic zone thus enhancing the productivity of the lake substantially (Kirilova et al. 2008). Cooler temperatures and prolonged ice cover is likely to have triggered a similar response in the phosphorus cycle of Sacrower See during the Younger Dryas cold phase.

At Meerfelder Maar (Germany) Brauer et al. (1999) reported on increased productivity levels during the Younger Dryas. However, they attribute this to nutrient enrichment by soil erosion. Schmidt et al. (2002) observed a TP increase in an unlaminated sediments of Längsee (Austria) caused by allochthonous sources rather then reflecting internal phosphorus loading. Although high Ti counts were observed in the Younger Dryas sediments of Sacrower See, suggesting an increase in erosive input, it seems very unlikely that all allochthonous sources could lead to TP values as high as $60-70 \mu \mathrm{g} \mathrm{L}^{-1}$ in a pristine landscape.

A positive relationship between temperature and the nutrient availability in lakes has been reported in a number of limnological studies (e.g., Heiri \& Lotter 2005; Lacoul \& Freedman 2005). Especially in mountain regions this relationship may be partly explained by higher human activity in the catchment of warmer lowland sites. An increase in nutrient concentrations is also commonly reported as a likely response of temperate and arctic freshwater systems to climatic warming (e.g., Hauer et al. 1997; Rouse et al. 1997). In contrast, however, the climatic change at the Younger Dryas/Holocene transition ( 11,600 cal. BP), in Europe associated with an abrupt summer temperature increase in the range of $2-4{ }^{\circ} \mathrm{C}$ (e.g., Lotter et al. 2000; Heiri et al. 2007) and a decrease in seasonality (Renssen \& Isarin 2001), leading to shorter ice cover, less pronounced stratification and weaker anoxia, led to a rapid decrease in nutrient levels of Sarower See (Fig. 5).

After $\sim 11,600 \mathrm{cal}$. BP DI-TP decreased to values of $\sim 10-20 \mu \mathrm{g} \mathrm{L}^{-1}$ that persisted throughout most of the early and mid-Holocene. Diatoms with eutrophic affinities still were present in the assemblages, although the abundances of mesotrophic diatoms increased (Fig. 5). Laminations are present in the entire lowermost section of the Sacrower See core (Fig. 2), reflecting a perseverance of anoxic conditions and the absence of bioturbation during the Lateglacial and the early Holocene until ca 8000 cal. BP. However, chironomids typical of cold hypolimnetic waters were found in the record during most of the Lateglacial and again from $c a 11,000$ cal. BP onwards. This suggests that, with the exception of the short interval between $c a 11,700$ and $11,000 \mathrm{cal}$. BP, when profundal chironomids were absent from the record, the anoxia did not affect the entire hypolimnion. Most of these deep-water chironomids, such as $\mathrm{Mi}$ cropsectra radialis-type, Heterotrissocladius grimshawi-type, and Micropsectra insignilobus-type, are 
typical for oligo- to mesotrophic lakes (Saether 1979), which is in good agreement with the DI-TP reconstruction.

Reduced TP concentrations were also reconstructed in Längsee (Austria) during the Allerød period ( $c a$ $14,000-12,700$ cal. BP) which seemed to be caused by continental climatic conditions initiating a meromictic mixing regime in the lake (Schmidt et al. 2002). However, we believe that diatom and chironomid assemblages do not support a stable meromixis at Sacrower See. The main reasons for this conclusion are the presence of profundal chironomid taxa during a large part of the Holocene, suggesting at least seasonal oxygen availability in the lake's hypolimnion. Furthermore, high percentages of Stephanodiscus spp. were observed. These diatoms are spring bloomers which require relatively high phosphorus values. This suggests a significant transport of phosphorus from the hypolimnion to epilimnetic waters at least during spring overturn, contradicting a stable meromixis of Sacrower See. The formation of varved sediments can be explained by the temporary formation of an anoxic hypolimnion in the winter (e.g., Lüder et al. 2006; Bluszcz et al. 2008; Kirilova et al. 2008), and reduced oxygen availability and biological activity in the bottom waters in the deepest section of the lake basin.

After $c a 8000$ cal. BP laminations are absent indicating bioturbation by benthic organisms and consequently higher oxygen levels at the lake bottom. Sergentia coracina-type has its first occurrences in the lake around this time. S. coracina-type is a profundaldwelling chironomid typical of mesotrophic lakes (Saether 1979) and known to tolerate low oxygen conditions. It is therefore likely that this chironomid colonized the deepest parts of Sacrower See and was at least partly responsible for the bioturbation of the sediments. The dominant diatom species found in this part of the record, C. cyclopuncta (Fig. 3), together with the high abundance of chrysophyte cysts (indicators of high Si:P, Fig. 5) are reflecting oligo- to mesotrophic conditions.

Most research shows elevated nutrient conditions during the Holocene due to increased temperatures and external nutrient input (e.g., Brauer et al. 1999; Lotter 2001; Baier et al. 2004; Brüchmann \& Negendank 2004). In the case of Sacrower See, however, both diatom and chironomid assemblages show stable oligo- to mesotrophic conditions and at least seasonally oxygenated hypolimnion throughout the warm Holocene.

From the Bronze Age onwards (ca 4000 cal. BP) human influence on the landscape intensified in many parts of Europe and has been recorded in a number of sediment sequences (e.g., Fritz 1989; Wunsam \& Schmidt 1995; Lotter 1999; Heiri \& Lotter 2003; Zolitschka et al. 2003; Dreßler et al. 2006).

At Sacrower See an increase in DI-TP to values of $30 \mu \mathrm{g} \mathrm{L}^{-1}$ is registered at $\sim 3500 \mathrm{cal}$. BP and first minor peaks in $\mathrm{Ti}$ in the sediments are apparent from $\sim 3000$ cal. BP onwards, indicating increased soil erosion (Fig.
5) (Enters et al. accepted). This suggests that the first significant anthropogenic impact in the catchment area of Sacrower See began during the Bronze Age. There is archeological evidence for a local settlement of this time (Gramsch 2001). However, erosive input as recorded by sedimentary Ti remained relatively low until the Medieval Ages. Diatom assemblages were still dominated by mesotrophic diatoms, but $S$. parvus, a diatom typical of hypertrophic conditions reappeared at abundances of up to $10 \%$ in some samples. In addition, the decrease of the chrysophyte cysts also suggests a decrease of the Si:P ratio and increased nutrient levels in the lake. Around this time $C$. cyclopuncta decreased and was progressively replaced by $C$. comensis and $S$. neoastraea. Around $\sim 4000$ cal. BP chironomids typical for oligotrophic systems, such as Heterotrissocladius grimshawitype and Tanytarsus lugens-type disappeared from the lake (Fig. 4). However, Micropsectra insignilobus-type, which is known to occur in oligo- to mesotrophic lakes (Saether 1979), persisted in Sacrower See until ca 2000 cal. BP and Sergentia coracina-type reached its highest abundances in this part of the sequence, suggesting at least seasonal oxygen availability in the deepest part of the lake basin.

Between $\sim 800$ and 300 cal. BP DI-TP increased to values between 30 and $40 \mu \mathrm{g} \mathrm{L}^{-1}$. This rise in DI-TP coincides with a distinct increase in Ti concentrations in the sediments, suggesting enhanced soil erosion (Fig. 5). However, according to the diatom flora the lake was still meso- to eutrophic (DI-TP $c a 40 \mu \mathrm{g} \mathrm{L}^{-1}$ ) until the beginning of the $17^{\text {th }}$ Century. From the 1870 s onwards annually laminated sediments were formed again. Together with DI-TP values of $c a 60 \mu \mathrm{g} \mathrm{L}^{-1}$ and the dominance of Stephanodiscus spp. this is strong evidence for an increase in nutrient loading. A geochemical study of Sacrower See varves provides additional evidence for the increase in the primary productivity during this period due to strong nutrient input from the catchment and the eutrophic River Havel, which led to subsequent anoxia (Lüder et al. 2006). Anoxic conditions in the lake's bottom waters are also supported by the absence of cold stenothermic profundal chironomids in the uppermost part of the sediment core. In contrast to the lowermost, Lateglacial sediments for which DI-TP also reached values of $>60 \mu \mathrm{g} \mathrm{L}^{-1}$, external nutrient loading is the major cause for the elevated trophic conditions in the lake's recent past.

\subsection{Reference conditions}

In a large part of Europe cultural eutrophication has affected lakes during the $20^{\text {th }}$ Century and especially since the 1950s. In recent years nutrient concentrations in many of these lakes have started to decline, largely due to the successful reduction of external nutrient loading, or due to measures to decrease the internal remobilization of phosphorus (e.g., Søndergaard et al. 2007). However, in many cases the question remains 
whether these lakes are close to attaining their "natural" nutrient level or whether additional efforts are needed to further decrease P loading, especially where lake ecosystems need to be restored due to legislative actions. For example, the European Water Framework Directive (European Union 2000) aims at reverting European inland waters to a "good ecological quality". In order to achieve this aim, the directive requires reference states that represent ecological conditions in the absence of human impact other than very minor influence (e.g., Bennion \& Battarbee 2007; Moss 2008). In this context the results from Sacrower See are noteworthy since they indicate two possible natural nutrient states for this lake depending on climatic conditions: one being mesooligotrophic throughout several millennia of the temperate interglacial, whereas the other is in the meso- to eutrophic range during the cold phase of the Lateglacial. Furthermore, our results also indicate that deep, stratified lakes such as Sacrower See, can develop highly anoxic conditions in the absence of human impact and that internal nutrient loading can be strongly influenced by climatic conditions. This implies that effects of past and ongoing climate change must be taken into account when defining reference states. Lake ecosystems in different climatic settings, such as the more pristine lakes in mountain regions, do not necessarily provide suitable analogues or limnological reference conditions for lowland lakes.

In a number of palaeolimnological studies top and bottom samples of short sediment cores are used to assess ecological conditions in lakes before and after human impact (Smol 2008). The rationale behind this approach is that the lowermost sediment in a short core will generally predate the $19^{\text {th }}$ Century industrial revolution and biotic assemblages in this sediment will therefore reflect ecosystem conditions before major eutrophication of the industrial period. However, our case study, as well as other examples (e.g., Fritz 1989; Heiri \& Lotter 2003; Bradshaw et al. 2005), indicate that the eutrophication history of lakes can be complex. For Sacrower See, for example, the first evidence of nutrient enrichment due to human activity can be found as early as the Bronze Age ( $\sim 3500$ cal. BP). In this lake it would therefore be necessary to reach a sediment depth of at least $550 \mathrm{~cm}$ to reconstruct ecological conditions before major human influence. This suggests that in regions with a long history of human settlement, agriculture, and land use, e.g. most of central and southern Europe, the results obtained with the palaeolimnological top-bottom approach should be interpreted with caution when defining undisturbed reference conditions for lakes. Individual detailed palaeolimnological studies reconstructing the trophic history of lakes will be necessary to document the applicability of the topbottom approach for a given region and to assess whether the pre-industrial sediments represent undisturbed reference conditions or simply the ecological state under more moderate human impact before peak eutrophication.

\section{CONCLUSIONS}

Many lake ecosystems have undergone dramatic changes in nutrient status since the onset of industrialization. The fact that lakes may have experienced distinct pre-industrial limnological changes due to human activity during prehistoric and historic times has been observed in a number of palaeolimnological studies. However, the present study provides a clear example of distinctly enhanced nutrient conditions in a lake during a period unaffected by human influence. At Sacrower See, these elevated nutrient conditions were most likely a consequence of the climatic conditions during the Younger Dryas cold phase and their effects on the duration of the lake's ice cover, leading to hypolimnetic oxygen depletion and internal phosphorus remobilization. We, therefore, conclude that the definition of (near) pristine, undisturbed reference conditions with regard to ecological status of a lake should take into account both the potential effects of climatic and human influences on a lake ecosystem. Pre-industrial ecosystem states may in many instances be appropriate analogues for defining lake quality standards. However, case-studies of long-term ecosystem development are important and necessary to define and evaluate such reference conditions, especially in regions with a long history of human activity. In Central Europe lake ecosystem conditions reconstructed for the early- to mid Holocene ( $c a 11,600-4000$ cal. BP) provide examples of stable lacustrine system states in the absence of human activity and under climatic conditions comparable to today.

\section{ACKNOWLEDGEMENTS}

We would like to thank C. Ohlendorf, B. Lüder and P. Bluszcz for their help in obtaining the sediment cores and S. Jahns for preliminary pollen data. We acknowledge the support by the Utrecht Centre of Geosciences (UCG) and the Centre for Wetland Ecology (CWE). This is Netherlands Research School of Sedimentary Geology (NSG) publication no. 20081201.

\section{REFERENCES}

Adler, S. \& T. Hübener. 2007. Spatial variability of diatom assemblages in surface lake sediments and its implication for transfer functions. J. Paleolimnol., 37: 573-590.

Anderson, N.J. 1997. Reconstructing historical phosphorus concentrations in rural lakes using diatom models. In: H. Tunney, O.T. Carton, P.C. Brookes and A.E. Johnston [Eds], Phosphorus Loss from Soil to Water. CAB International: $95-118$.

Asikainen C.A., P. Francus \& J. Brigham-Grette. 2007. Sedimentology, clay mineralogy and grain-size as indicators of $65 \mathrm{ka}$ of climate change from El'gygytgyn Crater Lake, Northeastern Siberia. J. Paleolimnol., 37:105-122.

Baier J., A. Lücke, J.F.W. Negendank, G.-H. Schleser \& B. Zolitschka. 2004. Diatom and geochemical evidence of 
mid-to late Holocene climatic changes at Lake Holzmaar, West-Eifel (Germany). Quaternary International, 113: 81-96.

Battarbee, R.W. 1973. A new method for estimating absolute microfossil numbers with special reference to diatoms. Limnol. Oceanogr., 18: 647-653.

Bennion, H., S. Juggins \& N.J. Anderson. 1996. Predicting epilimnetic phosphorus concentrations using an improved diatom-based transfer function and its application to lake eutrophication management. Environmental Science and Technology, 30: 2004-2007.

Bennion, H., D. Monteith, \& P. Appleby. 2000. Temporal and geographical variation in lake trophic status in the English Lake District: evidence from (sub)fossil diatoms and aquatic macrophytes. Freshwat. Biol., 45: 394-412.

Bennion, H. \& R.W. Battarbee. 2007. The European Union Water Framework Directive: opportunities for palaeolimnology. J. Paleolimnol., 38: 285-295.

Bluszcz, P., E. Kirilova, A.F. Lotter, C. Ohlendorf \& B. Zolitschka. 2008. Global radiation and onset of stratification as forcing factors of seasonal carbonate and organic matter flux dynamics in a hypertrophic hardwater lake (Sacrower See, Northeastern Germany). Aquat. Sci., 14: 73-98.

Bradshaw, E.G., P. Rasmussen \& B.V. Odgaard. 2005. Midto late-Holocene land-use change and lake development at Dallund So, Denmark: synthesis of multiproxy data, linking land and lake. The Holocene, 15: 1152-1162.

Brauer, A., C. Endres, C. Günter, T. Litt, M. Stebich \& J.F.W. Negendank. 1999. High resolution sediment and vegetation responses to Younger Dryas climate change in varved lake sediments from Meerfelder Maar, Germany. Quaternary Science Reviews, 18: 321-329.

Brauer, A., G.H. Haug, P. Dulski, D.M. Sigman \& J.F.W. Negendank. 2008. An abrupt wind shift in Western Europe at the onset of the Younger Dryas cold period. Nature Geoscience, 1: 520-523.

Brooks, S.J., H. Bennion \& H.J.B. Birks. 2001. Tracing lake trophic history with a chironomid-total phosphorus inference model. Freshwat. Biol., 46: 513-533.

Brooks, S.J., P.G. Langdon \& O. Heiri. 2007. The identification and use of Palaearctic Chironomidae larvae in palaeoecology. Quaternary Research Association Technical Guide 10: $276 \mathrm{pp}$.

Brundin, L. 1949. Chironomiden und andere Bodentiere der südschwedischen Urgebirgsseen. Institute of Freshwater Research Drottningholm, Report, 30: 1-914.

Brüchmann C. \& J.F.W. Negendank. 2004. Indication of climatically induced natural eutrophication during the early Holocene period, based on annually laminated sediment from Lake Holzmaar, Germany. Quaternary International, 123-125: 117-134.

Carignan, R. \& R.J. Flett. 1981. Postdepositional mobility of phosphorus in lake sediments. Limnol. Oceanogr., 26: 361-366.

Compère, P. 2001. Ulnaria (Kützing) Compère, a new genus name for Fragilaria subgen. Alterasynedra Lange-Bertalot with comments on the typification of Synedra Ehrenberg., p. 97-101. In: R. Jahn, J.P. Kociolek, A. Witkowski \& P. Compère [Eds], Lange-Bertalot-Festschrift. Studies on Diatoms. A.R.G. Ganther Verlag K.G.

Douglas, M.S.V. \& J.P. Smol. 1999. Freshwater diatoms as indicators of environmental change in the High Arctic. In: E.F. Stoermer \& J.P. Smol [Eds], The diatoms: application for the environmental and earth sciences. Cambridge University Press: 227-244.

Dreßler M., U. Selig, W. Dörfler, S. Adler, H. Schubert \& T. Hübener. 2006. Environmental changes and the Migration Period in northern Germany as reflected in the sediments of Lake Dudinghausen. Quaternary Research, 66: 25-37.
Engstrom, D.R., S.C. Fritz, J.E. Almendinger \& S. Juggins. 2000. Chemical and biological trends during lake evolution in recently deglaciated terrain. Nature, 408: 161-166.

Enters, D., E. Kirilova, A. Lotter, A. Lücke, J. Parplies, G. Kuhn, S. Jahns, B. Zolitschka. Climate change and human impact at Sacrower See (NE Germany) during the past 13,000 years: a geochemical record. J. Palaeolimnol.: accepted

European Union 2000. Directive 2000/60/EC of the European Parliament and of the Council of 23 October 2000 establishing a framework for Community action in the field of water policy. Off. J. Eur. Commun. L 327: 1-73.

Fritz, S. C. 1989. Lake development and limnological response to prehistoric and historic land-use in Diss, Norfolk, U.K. J. Ecol., 77: 182-202.

Gramsch, B. 2001. Die "Römerschanze" bei Potsdam-Sacrow. In: J. H. Schröder (Ed.), Geologie von Berlin und Brandenburg. Nr. 4: Potsdam und Umgebung. Selbstverlag Geowissenschaftler in Berlin und Brandenburg e.V., Berlin: 245-248.

Håkansson, H. 2002. A compilation and evalutation of species in the general Stephanodiscus, Cyclostephanos and Cyclotella with a new genus in the family Stephanodiscaceae. Diatom Research, 17: 1-139.

Hall, R.I. \& J.P. Smol. 1999. Diatoms as indicators of lake eutrophication. In: E.F. Stoermer \& J.P. Smol [Eds], The diatoms: application for the environmental and earth sciences. Cambridge University press: 128-168.

Hauer, F.R., J.S. Baron, D.H. Campbell, K.D. Fausch, S.W. Hostetler, G.H. Leavesey, P.R. Leavitt, D.M. McKnight \& J.A. Stanford. 1997. Assessment of climate change and freshwater ecosystems of he Rocky Mountains, USA and Canada. Hydrological Processes, 11: 903-924.

Heegaard, E., H.J.B. Birks \& R. Telford. 2005. Relationships between calibrated ages and depth in stratigraphical sequences: an estimation procedure by mixed-effect regression. The Holocene, 15: 612-618.

Heiri, O. \& A.F. Lotter. 2001. The effects of low count sums on quantitative environmental reconstructions: an example using subfossil chironomids. J. Paleolimnol., 26: 343-350.

Heiri, O. \& A.F. Lotter. 2003. 9000 years of chironomid assemblage dynamics in an Alpine lake: long-term trends, sensitivity to disturbance and resilience of the fauna. $J$. Paleolimnol., 30: 273-289.

Heiri, O. \& A.F. Lotter. 2005. Summer temperature reconstruction in the Alps based on fossil assemblages of aquatic organisms: a review. Boreas, 34: 506-516.

Heiri, O., W. Peeters, E.S., H. Cremer, W.Z. Hoek \& A.F. Lotter. 2007. Lateglacial summer temperatures $n$ the Northwest European lowlands: a chironomid record from Hijkermeer, the Netherlands. Quat. Sci. Rev., 26: 2420-2437.

Heiri, O. \& A.F. Lotter. 2008. Chironomidae (Diptera) in Alpine lakes in Switzerland: a study based on subfossil assemblages in lake surface sediments. Boletim do Museu Municipal do Funchal: 13: 177-184.

Int Panis, L., B. Goddeeris \& R. Verheyen. 1996. On the relationship between the vertical microdistribution and some adaptions to oxygen stress in littoral Chironomidae (Diptera). Hydrobiologia, 318: 61-67.

Itkonen, A., V. Marttila, J.J. Meriläinen \& V.-P. Salonen. 1999. 8000-year history of palaeoproductivity in a large boreal lake. J. Paleolimnol., 21: 271-294.

Juggins, S. 2007. C2 Version 1.5 User guide. Software for ecological and palaeoecological data analysis and visualisation. Newcastle University.

Kirilova, E.P., P. Bluszcz, O. Heiri, H. Cremer, C. Ohlendorf, A.F. Lotter \& B. Zolitschka. 2008. Seasonal and interannual dynamics of diatom assemblages in Sacrower See (NE Germany): a sediment trap study. Hydrobiologia, 614: $159-170$ 
Krammer, K. \& H. Lange-Bertalot. 1986. Bacillariophyceae. 1. Teil: Naviculaceae. G. Fischer Verlag.

Krammer, K. \& H. Lange-Bertalot.. 1988. Bacillariophyceae. 2. Teil: Bacillariaceae, Epithemiaceae, Surirellaceae. G. Fischer Verlag.

Krammer, K., \& H. Lange-Bertalot.. 1991a. Bacillariophyceae. 3. Teil: Centrales, Fragilariaceae, Eunotiaceae. G. Fischer Verlag.

Krammer, K. \& H. Lange-Bertalot.. 1991b. Bacillariophyceae. 4. Teil: Achnanthaceae, kritische Ergänzungen zu Navicula (Lineolatae) und Gomphonema. Gesamtliteraturverzeichnis Teil 1-4. G. Fischer Verlag.

Lacoul, P. \& B. Freedman. 2005. Physical and chemical limnology of 34 lentic waterbodies along a tropical-to-alpine altitudinal gradient in Nepal. Int. Rev. ges. Hydrobiol., 90: 254-276.

Little, J.L. \& J.P. Smol. 2001. A chironomid-based model for inferring late-summer hypolimnetic oxygen in southeastern Ontario lakes. J. Paleolimnol., 26: 259-270.

Lotter, A.F. 1998. The recent eutrophication of Baldeggersee (Switzerland) as assessed by fossil diatom assemblages. The Holocene, 8: 395-405.

Lotter, A.F. 1999: Late-glacial and Holocene vegetation history and dynamics as shown by pollen and plant macrofossil analyses in annually laminated sediments from Soppensee, central Switzerland. Vegetation History and Archaeobotany, 8: 165-184.

Lotter, A.F. 2001. The palaeolimnology of Soppensee (Central Switzerland), as evidenced by diatom, pollen, and fossilpigment analyses. J. Paleolimnol., 25: 65-79.

Lotter, A.F. \& C. Bigler. 2000. Do diatoms in the Swiss Alps reflect the length of ice-cover? Aquat. Sci., 62: 125-141.

Lotter, A.F., H.J.B. Birks, U. Eicher, W. Hofmann, J. Schwander \& L. Wick. 2000. Younger Dryas and Alleröd summer temperatures at Gerzensee (Switzerland) inferred from fossil pollen and cladoceran assemblages. Palaeogeography, Palaeoclimatology, Palaeoecology, 159: 349361.

Lotter, A.F., H.J.B. Birks, W. Hofmann \& A. Marchetto. 1998. Modern diatom, cladocera, chironomid, and chrysophyte cyst assemblages as quantitative indicators for the reconstruction of past environmental conditions in the Alps. II. Nutrients. J. Paleolimnol., 19: 443-463.

Lüder, B., G. Kirchner, A. Lücke \& B. Zolitschka. 2006. Palaeoenvironmental reconstrucitons based on geochemical parameters from annually laminated sediments of Sacrower See (northeastern Germany) since the $17^{\text {th }}$ Century. J. Paleolimnol., 35: 897-912.

Moss, B. 2008. Water pollution by agriculture. Philosophical Transaction of the Royal Society London, B, 363: 659666.

Moosmann, L., R. Gächter, B. Müller \& A. Wüest. 2006. Is phosphorus retention in autochthonous lake sediments controlled by oxygen or phosphorus? Limnol. Oceanogr., 51: 763-771.

Quinlan, R. \& J.P. Smol. 2001. Setting minimum head capsule abundance and taxa deletion criteria in chironomid-based inference models. J. Paleolimnol., 26: 327-342.

Reimer, P.J., M.G.L. Baillie, E. Bard, , A. Bayliss, J.W. Beck, C. Bertrand, P.G. Blackwell, C.E. Buck, G. Burr, K.B. Cutler, P.E. Damon, R.L. Edwards, R.G. Fairbanks, M. Friedrich, T.P. Guilderson, K.A. Hughen, B. Kromer, F.G.
McCormac, S.W. Manning, C. Bronk Ramsey, R.W. Reimer, S. Remmele, J.R. Southon, M. Stuiver, S. Talamo, F.W. Taylor, J. van der Plicht \& C.E. Weyhenmeyer. 2004. IntCal04 terrestrial radiocarbon age calibration, 0-26 cal kyr BP. Radiocarbon, 46: 1029-1058.

Renssen, H. \& R.F.B. Isarin. 2001. The two major warming phases of the last deglaciation at $\sim 14.7$ and $\sim 11.5 \mathrm{ka} \mathrm{cal}$ BP in Europe: climate reconstructions and AGCM experiments. Global and Planetary Change, 30: 117-153.

Round, F.E., R. Crawford \& D. Mann. 1990. The diatoms. Biology and morphology of the genera. Cambridge University Press.

Rouse, W.R., M.S.V. Douglas, R.E. Hecky, A.E. Hershey, G.W. Kling, L. Lesack, P. Marsh, M. McDonald, B.J. Nicholson, N.T. Roulet \& J.P. Smol. 1997. Effects of climate change on the freshwaters of arctic and subarctic North America. Hydrological Processes, 11: 873-902.

Saether, O.A. 1979. Chironomid communities as water quality indicators. Holarctic Ecology, 2: 65-74.

Schindler, D.W. 2001. The cumulative effects of climate warming and other human stresses on Canadian freshwaters in the new millennium. Can. J. Fish. Aquat. Sci., 58: 18-29.

Schmidt, R., R. Psenner, J. Müller, P. Indinger \& C. Kamenik. 2002. Impact of late glacial climate variations on stratification and trophic state of the meromictic Längsee (Austria): validation of a conceptual model by multi proxy studies. J. Limnol., 61: 49-60.

Smol, J.P. 2008. Pollution of Lake and Rivers: A Paleoenvironmental Perspective. 2nd Edition. Blackwell Publishing, Oxford. 383 pp.

Søndergaard, M., J.P. Jensen \& E. Jeppesen. 2001. Retention and internal loading of phosphorus in shallow, eutrophic lakes. The Scientific World, 1: 427-442.

Søndergaard, M., E. Jeppesen, T.L. Lauridsen, C. Skov, E.H. Van Nes, R. Roijackers, E. Lammens \& R. Portielje. 2007. Lake restoration: successes, failures and long-term effects. J. Appl. Ecol., 44: 1095-1105.

Spears, B.M., L. Carvalho, R. Perkins \& D.M. Paterson. 2008. Effects of light on sediment nutrient flux and water column nutrient stoichiometry in a shallow lake. Water Res., 42: $977-986$

Stoermer, E.F. \& J.P. Smol [Eds]. 1999. The diatoms: applications for the environmental and earth sciences. Cambridge University Press.

Ter Braak, C.J.F. \& S.Juggins. 1993. Weighted averaging partial least squares regression (WA-PLS): an improved method for reconstructing environmental variables from species assemblages. Hydrobiologia, 269/270: 485-502.

Van Dam, H., A. Mertens \& J. Sinkeldam. 1994. A coded checklist and ecological indicator values of freshwater diatoms from the Netherlands. Netherlands J. Aquat. Ecol., 28: 117-133.

Wunsam, S. \& R. Schmidt. 1995. A diatom-phosphorus transfer function for Alpine and pre-alpine lakes. Mem. Ist. ital. Idrobiol., 53: 85-99.

Zolitschka, B., K.-E. Behre \& J. Schneider. 2003. Human and climatic impact on the environment as derived from colluvial, fluvial and lacustrine archives - Examples from the Bronze Age to the Migration period, Germany. Quat. Sci. Rev., 22: 81-100. 